Article

\title{
Surface Modification of $\mathrm{Li}\left(\mathrm{Ni}_{0.6} \mathrm{Co}_{0.2} \mathrm{Mn}_{0.2}\right) \mathrm{O}_{2}$ Cathode Materials by Nano- $\mathrm{Al}_{2} \mathrm{O}_{3}$ to Improve Electrochemical Performance in Lithium-Ion Batteries
}

\author{
Kwang Soo Yoo ${ }^{1, *,+}$, Yeon Hui Kang ${ }^{1,2,+}$, Kyoung Ran $\operatorname{Im}^{3}$ and Chang-Sam Kim ${ }^{2, *}$ \\ 1 Department of Materials Science and Engineering, University of Seoul, 163, Seoulsiripdae-ro, \\ Dongdaemun-gu, Seoul 02504, Korea; yunhee813@naver.com \\ 2 Center for Energy Convergence Research, Korea Institute of Science and Technology, 5, Hwarang-ro 14-gil, \\ Seongbuk-gu, Seoul 02792, Korea \\ 3 G-Materials Co., Ltd., 649, Ori-ro, Gwangmyeong-si, Gyeonggi-do 14303, Korea; krhankyoung@gmail.com \\ * Correspondence: ksyoo@uos.ac.kr (K.S.Y.); cskim@kist.re.kr (C.-S.K.); \\ Tel.: +82-2-6490-2406 (K.S.Y.); +82-2-958-5483 (C.-S.K.) \\ + These authors contributed equally to this work.
}

Received: 28 September 2017; Accepted: 1 November 2017; Published: 6 November 2017

\begin{abstract}
Al}_{2} \mathrm{O}_{3}$-coated $\mathrm{Li}\left(\mathrm{Ni}_{0.6} \mathrm{Co}_{0.2} \mathrm{Mn}_{0.2}\right) \mathrm{O}_{2}$ cathode materials were prepared by simple surface modification in water media through a sol-gel process with a dispersant. The crystallinity and surface morphology of the samples were characterized through X-ray diffraction analysis and scanning electron microscopy observation. The $\mathrm{Li}\left(\mathrm{Ni}_{0.6} \mathrm{Co}_{0.2} \mathrm{Mn}_{0.2}\right) \mathrm{O}_{2}$ cathode material was of a polycrystalline hexagonal structure and agglomerated with particles of approximately 0.3 to $0.8 \mu \mathrm{m}$ in diameter. The nanosized $\mathrm{Al}_{2} \mathrm{O}_{3}$ particles of low concentration $(0.06-0.12 \mathrm{wt} \%)$ were uniformly coated on the surface of $\mathrm{Li}\left(\mathrm{Ni}_{0.6} \mathrm{Co}_{0.2} \mathrm{Mn}_{0.2}\right) \mathrm{O}_{2}$. Measurement of electrochemical properties showed that $\mathrm{Li}\left(\mathrm{Ni}_{0.6} \mathrm{Co}_{0.2} \mathrm{Mn}_{0.2}\right) \mathrm{O}_{2}$ coated with $\mathrm{Al}_{2} \mathrm{O}_{3}$ of $0.08 \mathrm{wt} \%$ had a high initial discharge capacity of $206.9 \mathrm{mAh} / \mathrm{g}$ at a rate of $0.05 \mathrm{C}$ over $3.0-4.5 \mathrm{~V}$ and high capacity retention of $94.5 \%$ at $0.5 \mathrm{C}$ after 30 cycles (cf. uncoated sample: $206.1 \mathrm{mAh} / \mathrm{g}$ and $90.8 \%$, respectively). The rate capability of this material was also improved, i.e., it showed a high discharge capacity of $166.3 \mathrm{mAh} / \mathrm{g}$ after 5 cycles at a rate of $2 \mathrm{C}$, whereas the uncoated sample showed $155.8 \mathrm{mAh} / \mathrm{g}$ under the same experimental conditions.
\end{abstract}

Keywords: lithium-ion batteries; Ni-rich cathode materials; nano- $\mathrm{Al}_{2} \mathrm{O}_{3}$ coating; surface modification; electrochemical property

\section{Introduction}

Current lithium-ion battery technology offers the highest energy density among the rechargeable battery technologies, dominating the market for mobile electronic devices for the past several decades. However, alternative forms of transportation, such as electric and plug-in hybrid electric vehicles, require significant improvements in energy density, safety, durability, cost, etc. The key to the successful development of novel and advanced rechargeable batteries is the materials [1].

Since Sony commercialized the lithium-ion secondary battery $\left(\mathrm{C} / \mathrm{LiCoO}_{2}\right.$ cell $)$ in 1991 , various cathode (positive electrode) materials, which account for approximately $30 \%$ of materials in the lithium-ion battery, have been studied by many investigators. $\mathrm{LiCoO}_{2}$ has been the dominating cathode material for commercial lithium-ion batteries owing to its high capacity, stable cycling, and easy production [2]. However, cobalt in $\mathrm{LiCoO}_{2}$ is a rare metal, expensive, and toxic, therefore alternative cathode materials such as ternary $\mathrm{Li}\left(\mathrm{Ni}_{1-\mathrm{x}-\mathrm{y}} \mathrm{Co}_{\mathrm{x}} \mathrm{Al}_{\mathrm{y}}\right) \mathrm{O}_{2}$ and $\mathrm{Li}\left(\mathrm{Ni}_{1-\mathrm{x}-\mathrm{y}} \mathrm{Co}_{\mathrm{x}} \mathrm{Mn}_{\mathrm{y}}\right) \mathrm{O}_{2}$ compounds with layered structures, spinel-structured $\mathrm{LiMn}_{2} \mathrm{O}_{4}$, olivine-structured $\mathrm{LiMPO}_{4}(\mathrm{M}=\mathrm{Fe}, \mathrm{Mn}, \mathrm{Co}, \mathrm{Ni})$, and 
orthosilicates $\mathrm{Li}_{2} \mathrm{MSiO}_{4}(\mathrm{M}=\mathrm{Fe}, \mathrm{Mn}, \mathrm{Co})$, have been intensively investigated [1,3-8]. Among these candidates, $\mathrm{Li}\left(\mathrm{Ni}_{1-\mathrm{x}-\mathrm{y}} \mathrm{Co}_{x} \mathrm{Mn}_{\mathrm{y}}\right) \mathrm{O}_{2}$ has been considered as a possible replacement for $\mathrm{LiCoO}_{2}$ [9-12].

Nickel-rich (Ni-rich) layered compounds $(1-\mathrm{x}-\mathrm{y} \geq 0.5)$, such as $\mathrm{Li}\left(\mathrm{Ni}_{0.6} \mathrm{Co}_{0.2} \mathrm{Mn}_{0.2}\right) \mathrm{O}_{2}$ are the most promising because high $\mathrm{Ni}$ and low Co content contributes to the improvement of specific capacity and the reduction of cost [10]. Recently, Erickson et al. [13] reported that cathodes prepared from Li-rich $x \mathrm{Li}_{2} \mathrm{MnO}_{3} \cdot(1-\mathrm{x}) \mathrm{Li}\left(\mathrm{Ni}_{\mathrm{a}} \mathrm{Co}_{\mathrm{b}} \mathrm{Mn}_{\mathrm{c}}\right) \mathrm{O}_{2}(\mathrm{a}+\mathrm{b}+\mathrm{c}=1)$ demonstrated extremely high discharge capacities. However, as the content of $\mathrm{Ni}$ in $\mathrm{Li}\left(\mathrm{Ni}_{1-\mathrm{x}-\mathrm{y}} \mathrm{Co}_{\mathrm{x}} \mathrm{Mn}_{\mathrm{y}}\right) \mathrm{O}_{2}$ increases, its thermal, structural, and chemical stabilities decrease [14-17]. Accordingly, the cathode materials with high capacity and good thermal stability, simultaneously, are necessary. This could be achieved by improving the degradation of the electrochemical properties and thermal stability in lithium-ion batteries caused by the interface reaction between the cathode material and the electrolyte solution. This problem could be solved by coating the surface of the cathode material with a different material. This surface modification technology was introduced for a $\mathrm{LiCoO}_{2}$ cathode by coating with metal oxides, such as $\mathrm{TiO}_{2}, \mathrm{Al}_{2} \mathrm{O}_{3}, \mathrm{Mg}_{2} \mathrm{TiO}_{4}$, and $\mathrm{NaAlO}_{2}$ [2,18-20]; $\mathrm{LiNi}_{0.5} \mathrm{Mn}_{1.5} \mathrm{O}_{4}$ cathode by $\mathrm{ZrO}_{2}, \mathrm{ZrP}_{2} \mathrm{O}_{7}$, and $\mathrm{AlPO}_{4}$ coating [21,22]; and $\mathrm{Li}\left(\mathrm{Ni}_{0.6} \mathrm{Co}_{0.2} \mathrm{Mn}_{0.2}\right) \mathrm{O}_{2}$ cathode by $\mathrm{TiO}_{2}, \mathrm{Al}_{2} \mathrm{O}_{3}$, and $\mathrm{Li}_{2} \mathrm{ZrO}_{3}$ coating [23-25]. Among the coating processes, wet chemical processes such as sol-gel and precipitation are widely applied, which typically require $0.3-5 \mathrm{wt} \%$ of coating material respect to the cathode material and resulted in substantially inhomogeneous coating. Recently ultrasonic-assisted process was introduced to coat $\mathrm{Li}\left(\mathrm{Ni}_{0.6} \mathrm{Co}_{0.2} \mathrm{Mn}_{0.2}\right) \mathrm{O}_{2}$ with nano- $\mathrm{Al}_{2} \mathrm{O}_{3}$; Chen et al. [24] reported that the electrochemical performance of a $\mathrm{Li}\left(\mathrm{Ni}_{0.6} \mathrm{Co}_{0.2} \mathrm{Mn}_{0.2}\right) \mathrm{O}_{2}$ cathode material coated with $\mathrm{Al}_{2} \mathrm{O}_{3}$ of $1.0 \mathrm{wt} \%$ showed initial discharge capacity of $197.1 \mathrm{mAh} / \mathrm{g}$ over $3.0-4.5 \mathrm{~V}$ and capacity retention of $91 \%$ after 30 cycles at 1 C. Here $\gamma-\mathrm{Al}_{2} \mathrm{O}_{3}$ nano-particles $\left(\mathrm{d}_{50}\right.$ ca. $\left.15 \mathrm{~nm}\right)$ and $\mathrm{Li}\left(\mathrm{Ni}_{0.6} \mathrm{Co}_{0.2} \mathrm{Mn}_{0.2}\right) \mathrm{O}_{2}$ powder were dispersed by ultrasonic treatment in ethanol, stirred, and subsequently evaporated the ethanol. Finally the dried sample was heat treated at $500{ }^{\circ} \mathrm{C}$ for $6 \mathrm{~h}$. The thickness of the coating layer is about $20-25 \mathrm{~nm}$. Therefore, it is desirable to develop a simple process to provide coating layers, which are substantially thin, discrete, and uniform to provide hindrance of the interfacial reaction of the electrode/electrolyte and little inhibition in the diffusion of $\mathrm{Li}^{+}$ions.

Herein, we demonstrate the use of simple surface modification in water media to improve the electrochemical properties, especially high capacity and stable cycling, of the $\mathrm{Li}\left(\mathrm{Ni}_{0.6} \mathrm{Co}_{0.2} \mathrm{Mn}_{0.2}\right) \mathrm{O}_{2}$ cathode. The $\mathrm{Al}_{2} \mathrm{O}_{3}$-coated $\mathrm{Li}\left(\mathrm{Ni}_{0.6} \mathrm{Co}_{0.2} \mathrm{Mn}_{0.2}\right) \mathrm{O}_{2}$ cathode materials were prepared by mixing cathode powder with $\mathrm{Al}_{2} \mathrm{O}_{3}$ precursor in water, drying the mixed slurry, and then annealing at various temperatures. The effects of the $\mathrm{Al}_{2} \mathrm{O}_{3}$ coating on the structural and electrochemical properties of the $\mathrm{Li}\left(\mathrm{Ni}_{0.6} \mathrm{Co}_{0.2} \mathrm{Mn}_{0.2}\right) \mathrm{O}_{2}$ cathode material were systematically investigated.

\section{Experimental Procedure}

The $\mathrm{Li}\left(\mathrm{Ni}_{0.6} \mathrm{Co}_{0.2} \mathrm{Mn}_{0.2}\right) \mathrm{O}_{2}$ cathode material $\left(\mathrm{d}_{10} / \mathrm{d}_{50} / \mathrm{d}_{90}=7.77 / 13.38 / 22.72 \mu \mathrm{m}\right)$ was a commercially available powder obtained from Ningbo Jinhe Lithium Battery Material Co., Ltd (Ningbo, China). Aqueous alumina $\left(\mathrm{Al}_{2} \mathrm{O}_{3}\right)$ sol was prepared with a concentration of $10 \mathrm{wt} \%$ by peptizing Boehmite $(\gamma-\mathrm{AlO}(\mathrm{OH}))$ powder in acidic water. This sol is viscous, translucent, and stable for several months. The $\mathrm{Li}\left(\mathrm{Ni}_{0.6} \mathrm{Co}_{0.2} \mathrm{Mn}_{0.2}\right) \mathrm{O}_{2}$ powder was added to a mixture of the alumina sol and an additive of polymeric dispersant based on polyethylene glycol in deionized water. The slurry concentration was approximately $80 \mathrm{wt} \%$. The amount of alumina sol that was used varied from 0.06 to $0.12 \mathrm{wt} \%$ as $\mathrm{Al}_{2} \mathrm{O}_{3}$ with respect to the $\mathrm{Li}\left(\mathrm{Ni}_{0.6} \mathrm{Co}_{0.2} \mathrm{Mn}_{0.2}\right) \mathrm{O}_{2}$ powder and the additive $0.04 \mathrm{wt} \%$. The mixture was mixed with a stirrer for $1 \mathrm{~h}$, heated to remove the water while stirring, and then dried in an oven. The dried coated powder was subjected to heat treatment at various temperatures from 400 to $600{ }^{\circ} \mathrm{C}$ and holding times varying from $2 \mathrm{~h}$ to $10 \mathrm{~h}$.

The structural properties of the $\mathrm{Al}_{2} \mathrm{O}_{3}$-coated $\mathrm{Li}\left(\mathrm{Ni}_{0.6} \mathrm{Co}_{0.2} \mathrm{Mn}_{0.2}\right) \mathrm{O}_{2}$ cathode materials were characterized by a powder X-ray diffractometer (XRD, Miniflex II, Rikagu, Tokyo, Japan) with a $2 \theta$ scan from 10 to $90^{\circ}$, where $\mathrm{Cu} \mathrm{K} \alpha(\lambda=1.5414 \AA)$ radiation was used for the X-ray source and the scan rate was $0.5^{\circ} / \mathrm{min}$. The surface morphologies of the cathode materials were observed using 
a scanning electron microscopy (SEM, Nova 200, FEI, Hillsboro, OR, USA) operating at $10 \mathrm{kV}$ and a scanning transmission electron microscopy (STEM, FEI, Talos F200X) operating at $200 \mathrm{kV}$ with an energy dispersive $\mathrm{X}$-ray spectrometer (EDS) for elemental mapping.

The cathode electrodes were prepared by mixing $\mathrm{Al}_{2} \mathrm{O}_{3}$-coated $\mathrm{Li}\left(\mathrm{Ni}_{0.6} \mathrm{Co}_{0.2} \mathrm{Mn}_{0.2}\right) \mathrm{O}_{2}$ as an active material, carbon black as a conducting material, and polyvinylidene difluoride (PVdF) as a binder with a weight ratio of 90:5:5; In addition, $N$-methyl pyrrolidone (NMP), as a solvent, was added to control the concentration of this slurry. The mixture was applied to aluminum foil and dried at $80^{\circ} \mathrm{C}$ for $2 \mathrm{~h}$ in a vacuum oven. The dried foil was hot-rolled to improve the adhesion between the active material and aluminum foil, and cut into circular discs of $14 \mathrm{~mm}$ in diameter. These discs were placed in a vacuum oven at $80^{\circ} \mathrm{C}$ for $24 \mathrm{~h}$ to vaporize any NMP that remained in the cathode.

To measure the electrochemical properties, standard coin cells (2032 type) were assembled inside a dry chamber and lithium foil was used as a counter electrode. The electrolyte was $1 \mathrm{M} \mathrm{LiPF}_{6}$ in a solution of ethylene carbonate, ethyl methyl carbonate, and dimethyl carbonate (1:1:1 in volume ratio). The charge and discharge tests were performed at various $C$ rates over the potential range of 3.0 to $4.5 \mathrm{~V}$ at room temperature using a galvanostatic cycling system (WBCS-3000, WonAtech, Seoul, Korea). The charge and discharge tests were conducted as one cycle at $0.5 \mathrm{C}, 2$ cycles at $0.1 \mathrm{C}$ and $0.2 \mathrm{C}, 5$ cycles at $0.5 \mathrm{C}, 1 \mathrm{C}$, and $2 \mathrm{C}$, and then 30 cycles at $0.5 \mathrm{C}$ for cycle performance. Thus, in this experiment, the total number of charge and discharge cycles was 53 . Tests were carried out with 3 samples, and leave out the off value and take an average of the two.

\section{Results and Discussion}

The strategy attempted here is to produce a very thin and uniform $\mathrm{Al}_{2} \mathrm{O}_{3}$ coating on the $\mathrm{Li}\left(\mathrm{Ni}_{0.6} \mathrm{Co}_{0.2} \mathrm{Mn}_{0.2}\right) \mathrm{O}_{2}$ cathode material by simply modifying a sol-gel process with a dispersant. This was accomplished through the following steps: the preparation of a stabilized coating solution, acid-base adsorption, a sol-gel process to form the thin film on the surface of the $\mathrm{Li}\left(\mathrm{Ni}_{0.6} \mathrm{Co}_{0.2} \mathrm{Mn}_{0.2}\right) \mathrm{O}_{2}$ powder, and a subsequent heat treatment step. Because the aqueous slurry of the $\mathrm{Li}\left(\mathrm{Ni}_{0.6} \mathrm{Co}_{0.2} \mathrm{Mn}_{0.2}\right) \mathrm{O}_{2}$ is basic, an acidic coating solution is preferred. The coating solution should be homogeneous and stable, so that the coating solution can be uniformly adsorbed on the surface of the $\mathrm{Li}\left(\mathrm{Ni}_{0.6} \mathrm{Co}_{0.2} \mathrm{Mn}_{0.2}\right) \mathrm{O}_{2}$ powder. Proper additives are helpful to stabilize the coating solution as well as to disperse the $\mathrm{Li}\left(\mathrm{Ni}_{0.6} \mathrm{Co}_{0.2} \mathrm{Mn}_{0.2}\right) \mathrm{O}_{2}$ powder in water. The adsorbed coating solution yields ultrathin films on the powder via gelling upon drying. These ultrathin films decompose to nano- $\mathrm{Al}_{2} \mathrm{O}_{3}$ upon heat treatment yielding adherent nano- $\mathrm{Al}_{2} \mathrm{O}_{3}$ particulates on the surface of the $\mathrm{Li}\left(\mathrm{Ni}_{0.6} \mathrm{Co}_{0.2} \mathrm{Mn}_{0.2}\right) \mathrm{O}_{2}$ powder. To date, surface modification using wet processes has employed considerably large quantities of the $\mathrm{Al}_{2} \mathrm{O}_{3}$ precursor from 0.3 to $5 \mathrm{wt} \%$. In the present study, we tried with a very low quantity of the $\mathrm{Al}_{2} \mathrm{O}_{3}$ precursor so that the solution coats the surface of the $\mathrm{Li}\left(\mathrm{Ni}_{0.6} \mathrm{Co}_{0.2} \mathrm{Mn}_{0.2}\right) \mathrm{O}_{2}$ powder well and evenly. Moreover, coating of excess $\mathrm{Al}_{2} \mathrm{O}_{3}$ than the appropriate amount that will result in the deterioration of the electrochemical properties can be avoided.

The results obtained by using a low concentration of the coating material are shown in Figure 1. The amount of $\mathrm{Al}_{2} \mathrm{O}_{3}$ in the sol was varied: $0.06 \mathrm{wt} \%$ for Figure $1 \mathrm{a}, 0.08 \mathrm{wt} \%$ for Figure $1 \mathrm{~b}$, and $0.12 \mathrm{wt} \%$ for Figure 1c. As the amount of $\mathrm{Al}_{2} \mathrm{O}_{3}$ increased, the adherent nano- $\mathrm{Al}_{2} \mathrm{O}_{3}$ also increased. The $\mathrm{Al}_{2} \mathrm{O}_{3}$ phase obtained by heat treatment at $500{ }^{\circ} \mathrm{C}$ for $4 \mathrm{~h}$ was $\gamma-\mathrm{Al}_{2} \mathrm{O}_{3}$, and this phase was maintained up to $700{ }^{\circ} \mathrm{C}$ [26]. The nanoparticles were dispersed uniformly and discretely in all three samples. Because $0.12 \mathrm{wt} \%$ of $\mathrm{Al}_{2} \mathrm{O}_{3}$ resulted in too many nanoparticles, $0.08 \mathrm{wt} \%$ of $\mathrm{Al}_{2} \mathrm{O}_{3}$ was chosen as a suitable amount for the $\mathrm{Li}\left(\mathrm{Ni}_{0.6} \mathrm{Co}_{0.2} \mathrm{Mn}_{0.2}\right) \mathrm{O}_{2}$ powder. This was also supported by their electrochemical performance for the samples heat treated at $600{ }^{\circ} \mathrm{C}$ for $4 \mathrm{~h}$ as shown in Figure 2a. Thus, further studies were performed with this composition of $0.08 \mathrm{wt} \% \mathrm{Al}_{2} \mathrm{O}_{3}$. 


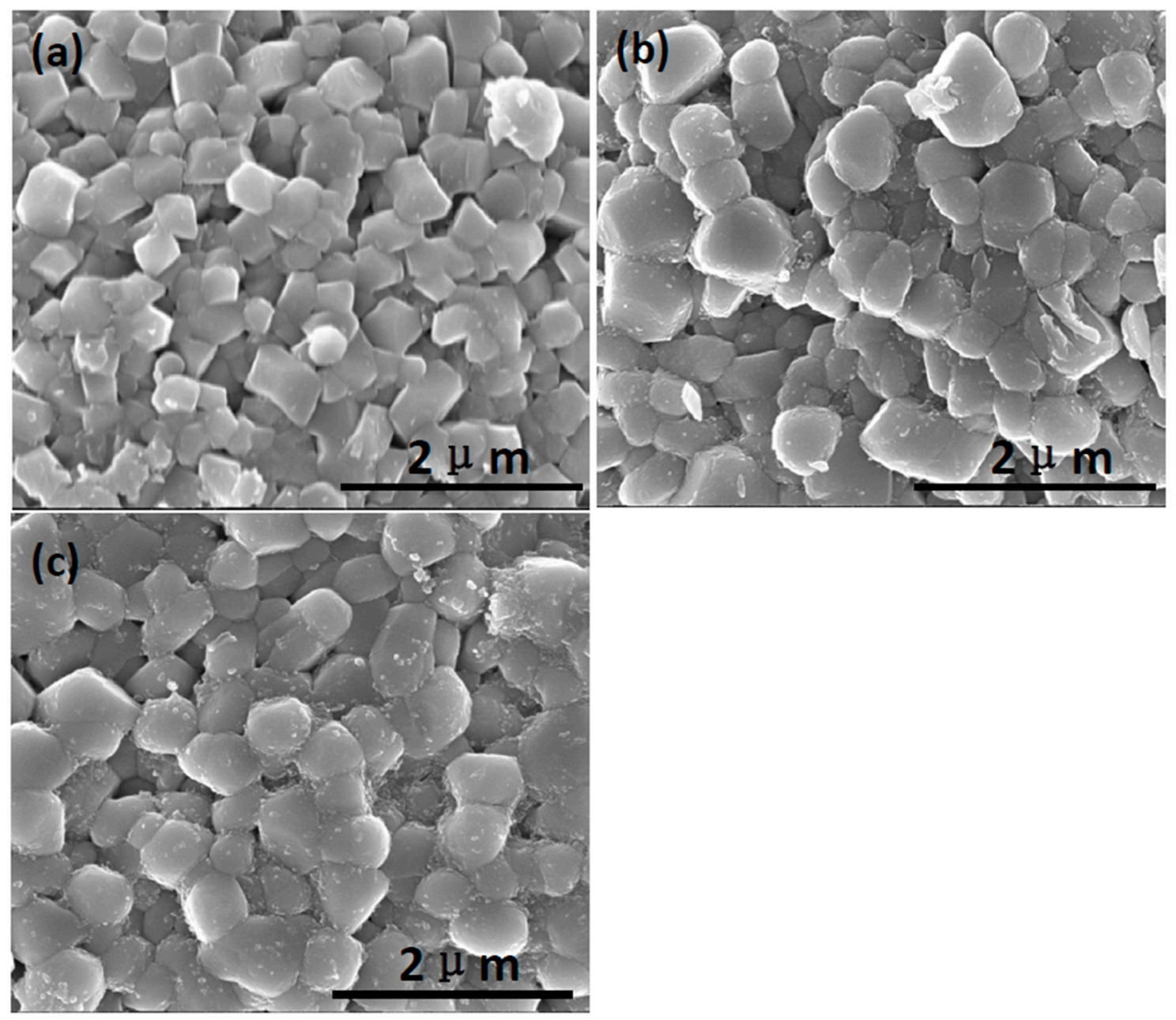

Figure 1. SEM images of the $\mathrm{Li}\left(\mathrm{Ni}_{0.6} \mathrm{Co}_{0.2} \mathrm{Mn}_{0.2}\right) \mathrm{O}_{2}$ powders coated with (a) $0.06 \mathrm{wt} \%$; (b) $0.08 \mathrm{wt} \%$; and (c) $0.12 \mathrm{wt} \%$ as $\mathrm{Al}_{2} \mathrm{O}_{3}$, and annealed at $500{ }^{\circ} \mathrm{C}$ for $4 \mathrm{~h}$.
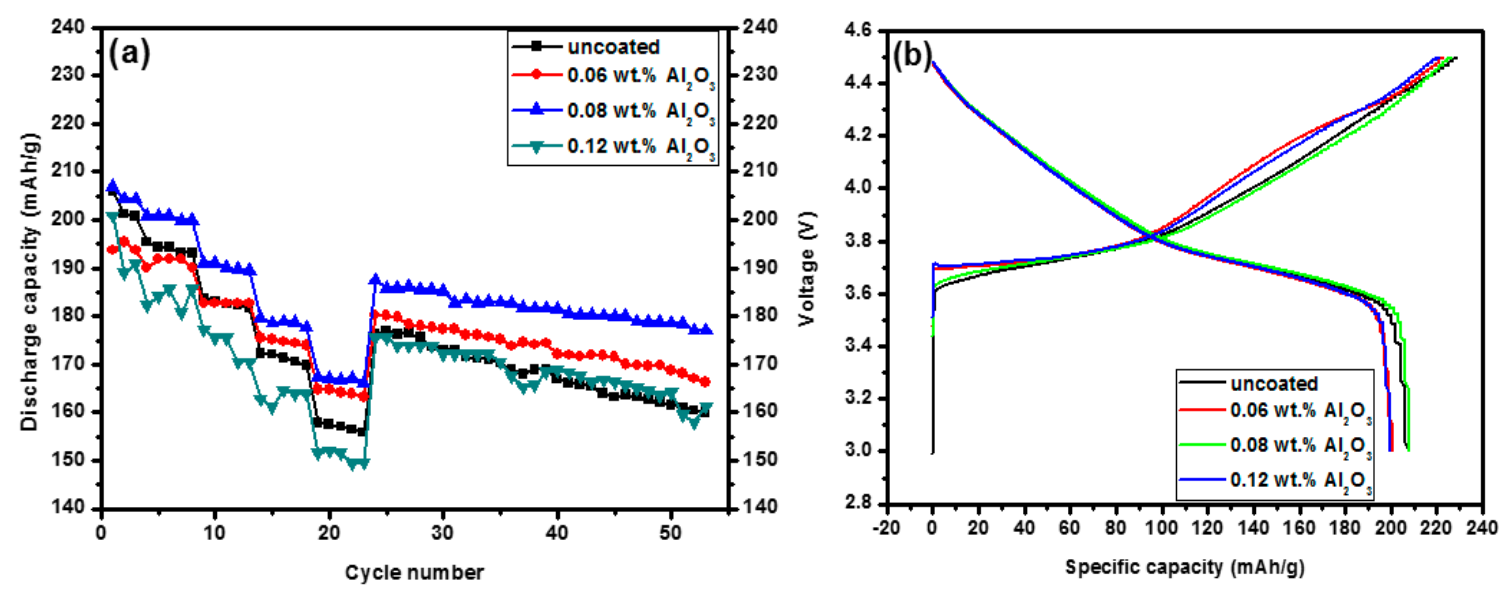

Figure 2. Cont. 

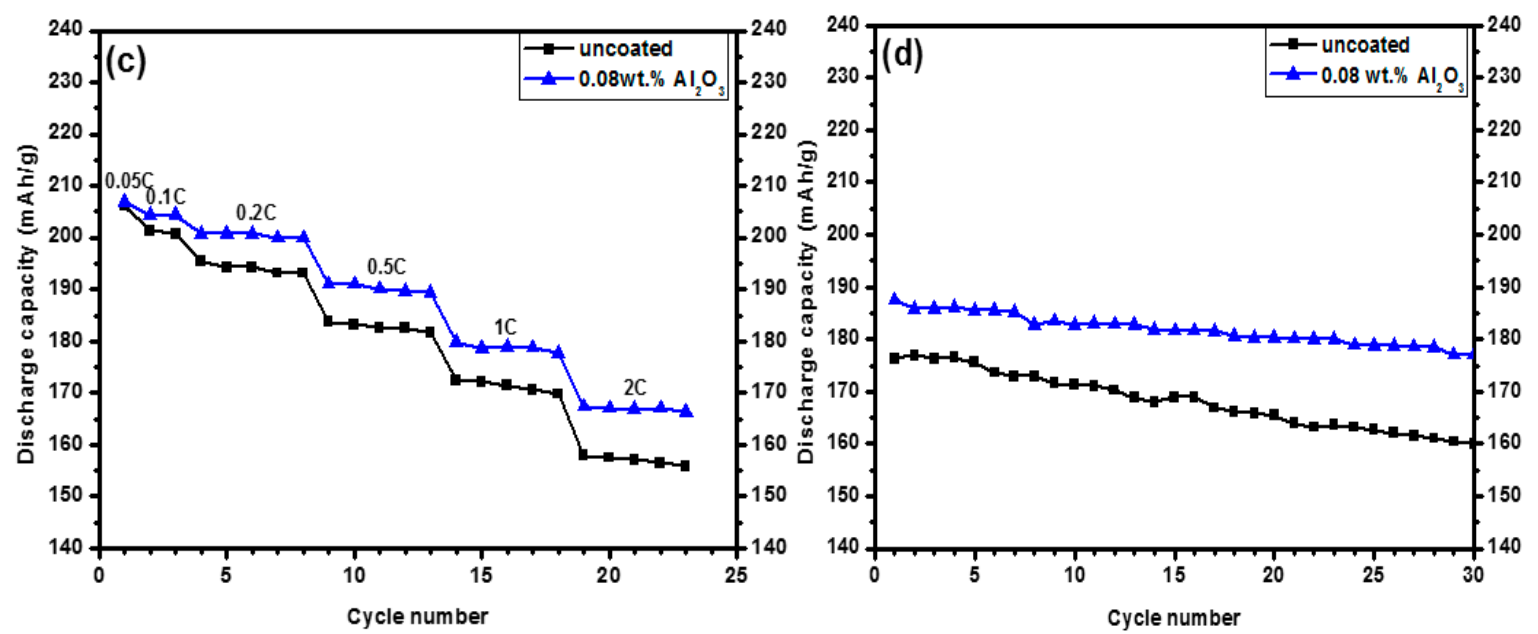

Figure 2. Electrochemical performance of the $\mathrm{Li}\left(\mathrm{Ni}_{0.6} \mathrm{Co}_{0.2} \mathrm{Mn}_{0.2}\right) \mathrm{O}_{2}$ samples uncoated and coated with different amounts of $\mathrm{Al}_{2} \mathrm{O}_{3}$ annealed at $600{ }^{\circ} \mathrm{C}$ for $4 \mathrm{~h}$ and cycled between 3.0 and $4.5 \mathrm{~V}$; (a) Discharge capacity vs. cycle number; (b) initial charge and discharge curves; (c) rate capability, and (d) cycling performance operated at a rate of $0.5 \mathrm{C}$.

\subsection{Structural Properties}

The XRD analysis of the uncoated and $\mathrm{Al}_{2} \mathrm{O}_{3}$-coated $\mathrm{Li}\left(\mathrm{Ni}_{0.6} \mathrm{Co}_{0.2} \mathrm{Mn}_{0.2}\right) \mathrm{O}_{2}$ samples was performed to determine the effect of the $\mathrm{Al}_{2} \mathrm{O}_{3}$ coatings on the crystal structure of $\mathrm{Li}\left(\mathrm{Ni}_{0.6} \mathrm{Co}_{0.2} \mathrm{Mn}_{0.2}\right) \mathrm{O}_{2}$. Figure 3 shows the XRD patterns of $\mathrm{Li}\left(\mathrm{Ni}_{0.6} \mathrm{Co}_{0.2} \mathrm{Mn}_{0.2}\right) \mathrm{O}_{2}$ uncoated and coated with $0.08 \mathrm{wt} \% \mathrm{Al}_{2} \mathrm{O}_{3}$ annealed at $600{ }^{\circ} \mathrm{C}$ for 2, 4, and $10 \mathrm{~h}$. As shown in Figure $3 \mathrm{a}$, the uncoated $\mathrm{Li}\left(\mathrm{Ni}_{0.6} \mathrm{Co}_{0.2} \mathrm{Mn}_{0.2}\right) \mathrm{O}_{2}$ sample was a hexagonal $\alpha-\mathrm{NaFeO}_{2}$ type structure with a space group of $\mathrm{R} \overline{\mathrm{m}} \mathrm{m}$ which agreed well with the JCPDS 87-1564 [27] and many earlier results [9,24,28,29]. There was no significant change in the XRD patterns for the $0.08 \mathrm{wt} \% \mathrm{Al}_{2} \mathrm{O}_{3}$ coated $\mathrm{Li}\left(\mathrm{Ni}_{0.6} \mathrm{Co}_{0.2} \mathrm{Mn}_{0.2}\right) \mathrm{O}_{2}$ samples compared to the uncoated $\mathrm{Li}\left(\mathrm{Ni}_{0.6} \mathrm{Co}_{0.2} \mathrm{Mn}_{0.2}\right) \mathrm{O}_{2}$ sample. No impurity peak was observed from the XRD patterns.

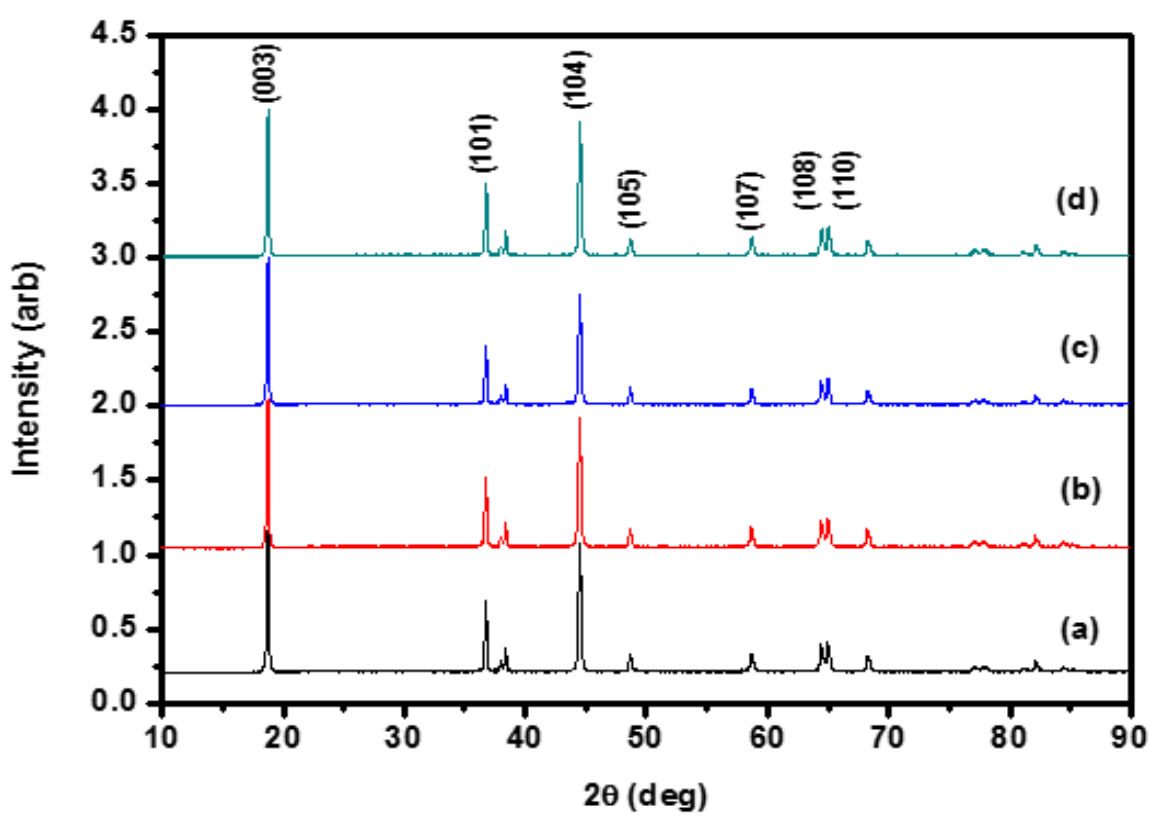

Figure 3. X-ray diffraction patterns of the $\mathrm{Li}\left(\mathrm{Ni}_{0.6} \mathrm{Co}_{0.2} \mathrm{Mn}_{0.2}\right) \mathrm{O}_{2}$ samples uncoated and coated with $0.08 \mathrm{wt} \% \mathrm{Al}_{2} \mathrm{O}_{3}$ annealing at $600{ }^{\circ} \mathrm{C}$ for 2,4 , and $10 \mathrm{~h}$, respectively. (a) Uncoated; (b) annealed at $600{ }^{\circ} \mathrm{C}$ for $2 \mathrm{~h}$; (c) annealed at $600{ }^{\circ} \mathrm{C}$ for $4 \mathrm{~h}$; and (d) annealed at $600{ }^{\circ} \mathrm{C}$ for $10 \mathrm{~h}$. 
The effects of heat treatment were observed by SEM, and the results are shown in Figure 4. The samples dried at $150{ }^{\circ} \mathrm{C}$ (Figure $4 \mathrm{a}$ ) and the annealed at $600{ }^{\circ} \mathrm{C}$ for $2 \mathrm{~h}$ (Figure $4 \mathrm{~b}$ ) show uniformly dispersed discrete nano- $\mathrm{Al}_{2} \mathrm{O}_{3}$ coated $\mathrm{Li}\left(\mathrm{Ni}_{0.6} \mathrm{Co}_{0.2} \mathrm{Mn}_{0.2}\right) \mathrm{O}_{2}$ particles while maintaining the morphology of the pristine, but the discrete nano- $\mathrm{Al}_{2} \mathrm{O}_{3}$ particles were mostly disappeared and the sharp-edged morphology was developed after the heat treatment at $600{ }^{\circ} \mathrm{C}$ for $4 \mathrm{~h}$ (Figure $4 \mathrm{c}$ ) and for $10 \mathrm{~h}$ (Figure $4 \mathrm{~d}$ ). It is noticeable that drying at $150{ }^{\circ} \mathrm{C}$ yields discrete adherent Boehmite nano-particles that resulted from the loss of volatiles of the films on the surface of the $\mathrm{Li}\left(\mathrm{Ni}_{0.6} \mathrm{Co}_{0.2} \mathrm{Mn}_{0.2}\right) \mathrm{O}_{2}$ powder. This supports our strategy to produce thin films on the surface via a sol-gel process. Heat treatment at $600{ }^{\circ} \mathrm{C}$ transforms the phase to $\gamma$ phase of discrete nano- $\mathrm{Al}_{2} \mathrm{O}_{3}$. The adherent nano- $\mathrm{Al}_{2} \mathrm{O}_{3}$ particles remain as coated particles at $600{ }^{\circ} \mathrm{C}$ for $2 \mathrm{~h}$ and seem to move to the cathode lattice upon heat treatment such as at $600{ }^{\circ} \mathrm{C}$ for $>4 \mathrm{~h}$. This observation is consistent with the findings of Dogan, who observed the transformation from "surface coating" to "dopants" by annealing at high temperature in $\mathrm{LiCoO}_{2}$ but not in $\mathrm{Li}\left(\mathrm{Ni}_{0.5} \mathrm{Co}_{0.2} \mathrm{Mn}_{0.3}\right) \mathrm{O}_{2}$ [30].

The elemental distribution of the $\mathrm{Li}\left(\mathrm{Ni}_{0.6} \mathrm{Co}_{0.2} \mathrm{Mn}_{0.2}\right) \mathrm{O}_{2}$ samples in Figure 4 was studied using an EDS under STEM mode. As shown in Figure 5, Figure 5a is an image of the $\mathrm{Li}\left(\mathrm{Ni}_{0.6} \mathrm{Co}_{0.2} \mathrm{Mn}_{0.2}\right) \mathrm{O}_{2}$ sample with the $0.08 \mathrm{wt} \% \mathrm{Al}_{2} \mathrm{O}_{3}$ coating that had been annealed at $600{ }^{\circ} \mathrm{C}$ for $4 \mathrm{~h}$, Figure $5 \mathrm{~b}$ is a high-angle annular dark-field (HAADF) image of the EDS mapping region, and Figure $5 \mathrm{c}-\mathrm{h}$ shows the distribution of $\mathrm{Al}, \mathrm{Co}, \mathrm{Mn}, \mathrm{Ni}$, and $\mathrm{O}$ in $\mathrm{HAADF}$ image, respectively. All elements are uniformly distributed on the surface of the $\mathrm{Al}_{2} \mathrm{O}_{3}$-coated $\mathrm{Li}\left(\mathrm{Ni}_{0.6} \mathrm{Co}_{0.2} \mathrm{Mn}_{0.2}\right) \mathrm{O}_{2}$ particles. EDS mapping of $\mathrm{Al}$ shows a uniform distribution on the surface, except for bright bands at the edges as shown in Figure $5 \mathrm{c}$ and the $\mathrm{Al}_{2} \mathrm{O}_{3}$ coating layer (red color, 10-15 nm in thickness) was confirmed from Figure $5 \mathrm{~h}$.
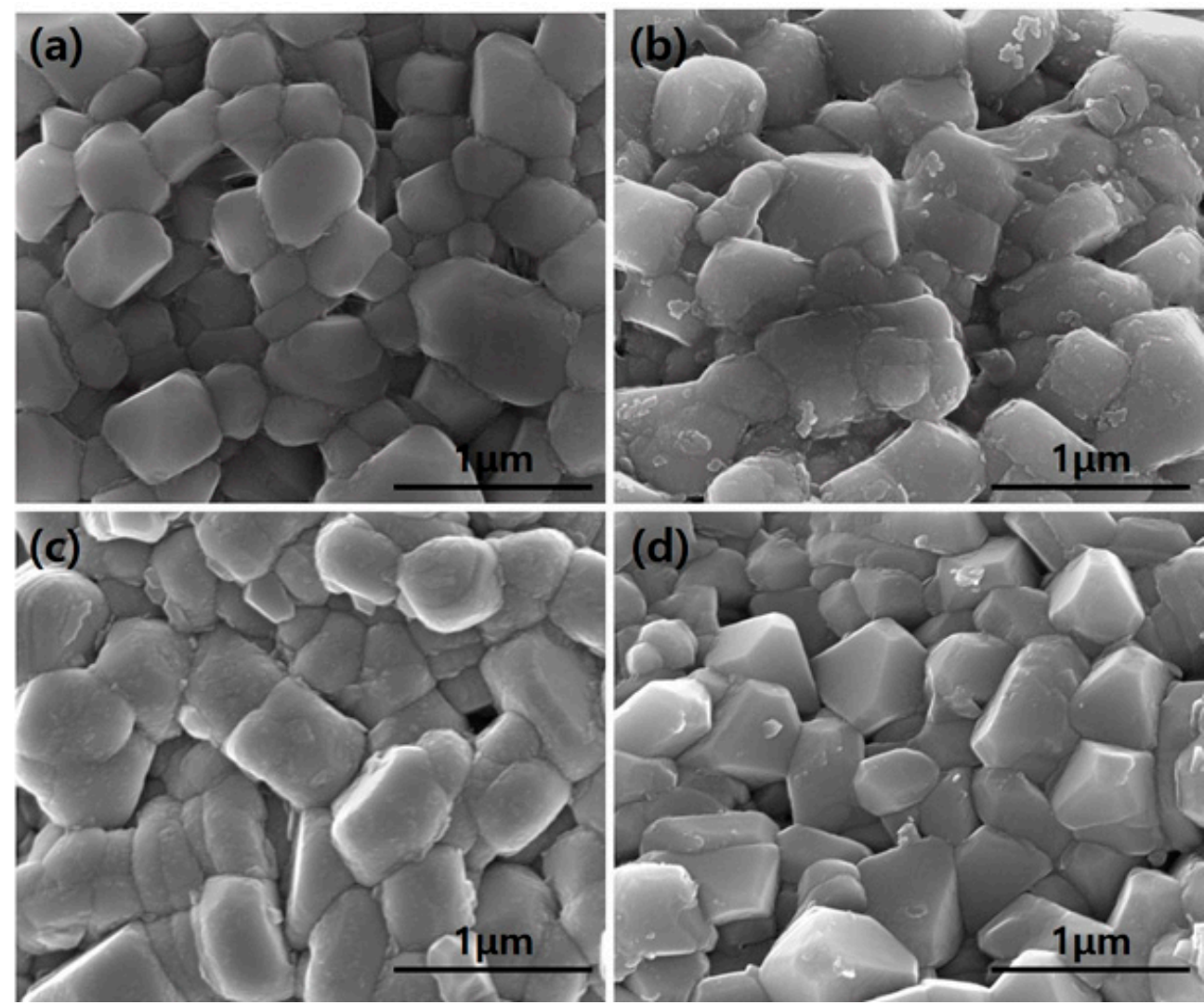

Figure 4. SEM images of the $\mathrm{Li}\left(\mathrm{Ni}_{0.6} \mathrm{Co}_{0.2} \mathrm{Mn}_{0.2}\right) \mathrm{O}_{2}$ samples (a) uncoated without heat treatment (dried at $150{ }^{\circ} \mathrm{C}$ ) and (b-d) coated with $0.08 \mathrm{wt} \% \mathrm{Al}_{2} \mathrm{O}_{3}$ annealing at $600{ }^{\circ} \mathrm{C}$ for 2,4 , and $10 \mathrm{~h}$, respectively. 


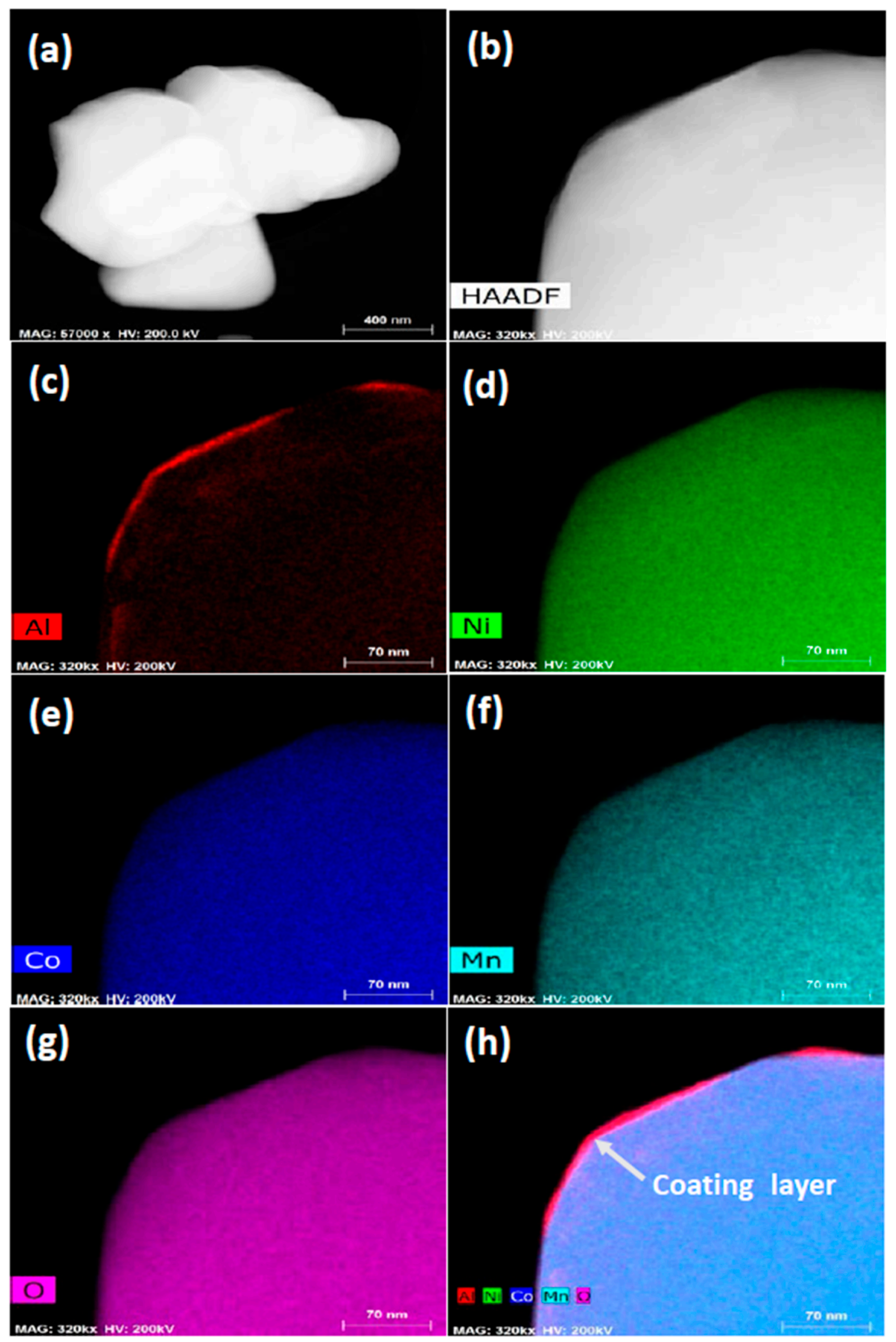

Figure 5. (a,b) Images of the EDS mapping region; and (c-h) the elemental mappings of the $0.08 \mathrm{wt} \%$ $\mathrm{Al}_{2} \mathrm{O}_{3}$-coated $\mathrm{Li}\left(\mathrm{Ni}_{0.6} \mathrm{Co}_{0.2} \mathrm{Mn}_{0.2}\right) \mathrm{O}_{2}$ sample annealed at $600{ }^{\circ} \mathrm{C}$ for $4 \mathrm{~h}$.

\subsection{Electrochemical Properties}

In order to study the electrochemical performance of $\mathrm{Li}\left(\mathrm{Ni}_{0.6} \mathrm{Co}_{0.2} \mathrm{Mn}_{0.2}\right) \mathrm{O}_{2}$ samples coated with different amounts of $\mathrm{Al}_{2} \mathrm{O}_{3}$, coin cells were operated at various $\mathrm{C}$ rates within the cutoff voltage of 3.0-4.5 V.

Figure 2 shows the electrochemical properties of the uncoated and $\mathrm{Al}_{2} \mathrm{O}_{3}$-coated samples annealed at $600{ }^{\circ} \mathrm{C}$ for $4 \mathrm{~h}$ between 3.0 and $4.5 \mathrm{~V}$. Figure 2a shows the discharge capacity versus the total number of cycles according to the experimental procedure, as explained before. For detailed analysis, initial charge-discharge curves, rate capability, and cycle performance are displayed in Figure $2 b-d$, respectively. Figure $2 b$ shows the initial charge-discharge curves of the samples cycled at a rate of $0.05 \mathrm{C}$. The initial discharge capacities for the samples uncoated and coated with $0.06,0.08$, and $1.2 \mathrm{wt} \% \mathrm{Al}_{2} \mathrm{O}_{3}$ were 206.1, 
200.6, 206.9, and 199.6 mAh/g, respectively. As shown in Figure 2a, the $0.08 \mathrm{wt} \% \mathrm{Al}_{2} \mathrm{O}_{3}$-coated sample exhibits a good rate capability. Figure 2c shows the change in discharge capacities of the uncoated sample and the $\mathrm{Al}_{2} \mathrm{O}_{3}$-coated sample at various $\mathrm{C}$ rates. The discharge capacities of the uncoated sample were 206.1, 200.7, 193.1, 181.7, 169.8, and 155.8 mAh/g at 0.05 C, $0.1 \mathrm{C}, 0.2 \mathrm{C}, 0.5 \mathrm{C}, 1 \mathrm{C}$, and $2 \mathrm{C}$, respectively. Under the same conditions, the discharge capacities of the $0.08 \mathrm{wt} \% \mathrm{Al}_{2} \mathrm{O}_{3}$-coated sample were 206.9, 204.3, 199.9, 189.5, 177.7, and $166.3 \mathrm{mAh} / \mathrm{g}$. With an increase in the $\mathrm{C}$ rate, i.e., the current density, the discharge capacity of the uncoated and $\mathrm{Al}_{2} \mathrm{O}_{3}$-coated sample both decrease, while the coated sample demonstrates a smaller discharge capacity decrease than the uncoated sample. The first discharge capacities were 206.1 and $206.9 \mathrm{mAh} / \mathrm{g}$ for the uncoated and coated samples, respectively; these samples had similar initial capacities. However, their discharge capacities after five cycles at a rate of $2 \mathrm{C}$ were 155.8 and $166.3 \mathrm{mAh} / \mathrm{g}$, respectively, demonstrating a notable difference in their values. The $\mathrm{Al}_{2} \mathrm{O}_{3}$-coated sample had a far greater improved rate capability than the uncoated sample. It is well known that the high rate capability of the coated sample is primarily due to the $\mathrm{Al}_{2} \mathrm{O}_{3}$ coating which protects the cathode material from reacting with electrolyte [24,31]. After being cycled from $0.05 \mathrm{C}$ to $2 \mathrm{C}$, the recovered discharge capacity of $187.5 \mathrm{mAh} / \mathrm{g}$ at $0.5 \mathrm{C}$ is almost identical to the initial discharge capacity at $0.5 \mathrm{C}$. This result indicates that there is good structural stability in the coated sample. The cycling performances of the uncoated and $\mathrm{Al}_{2} \mathrm{O}_{3}$-coated samples at $0.5 \mathrm{C}$ over 3.0-4.5 V are shown in Figure $2 \mathrm{a}$, d. The 0.08 wt $\% \mathrm{Al}_{2} \mathrm{O}_{3}$-coated sample after 30 cycles also exhibited the best capacity retention of $94.5 \%$, while the capacity retention of the uncoated sample was $90.8 \%$. This indicates that the cycling stability of the $0.08 \mathrm{wt} \% \mathrm{Al}_{2} \mathrm{O}_{3}$-coated sample could be improved by $\mathrm{Al}_{2} \mathrm{O}_{3}$ coating.

The effects of the temperature and holding time of heat treatment on the electrochemical properties of the $\mathrm{Al}_{2} \mathrm{O}_{3}$-coated samples are shown in Figures 6 and 7, respectively. As shown in Figure 6, by increasing the temperature from 400 to 500 , and $600^{\circ} \mathrm{C}$ with the fixed duration of $10 \mathrm{~h}$, the rate capability was improved for all the annealed samples, whereas the one at $500{ }^{\circ} \mathrm{C}$ showed better rate capability than that at $600{ }^{\circ} \mathrm{C}$. But they became showing similarly improved cycling performances. Considering the SEM images in Figure 4, the coated nano- $\mathrm{Al}_{2} \mathrm{O}_{3}$ particles work better than the doped $\mathrm{Al}_{2} \mathrm{O}_{3}$ in the rate capability, but both improve the cycling performance similarly. As per holding time effects as shown in Figure 7, significant improvement in electrochemical performances were observed for both $4 \mathrm{~h}$ and $10 \mathrm{~h}$ at almost same extent, whereas only moderate improvement is observed for $2 \mathrm{~h}$. Duration time of $4 \mathrm{~h}$ at $600^{\circ} \mathrm{C}$ shows improvement as good as $10 \mathrm{~h}$ in both rate capability and cycling performance.

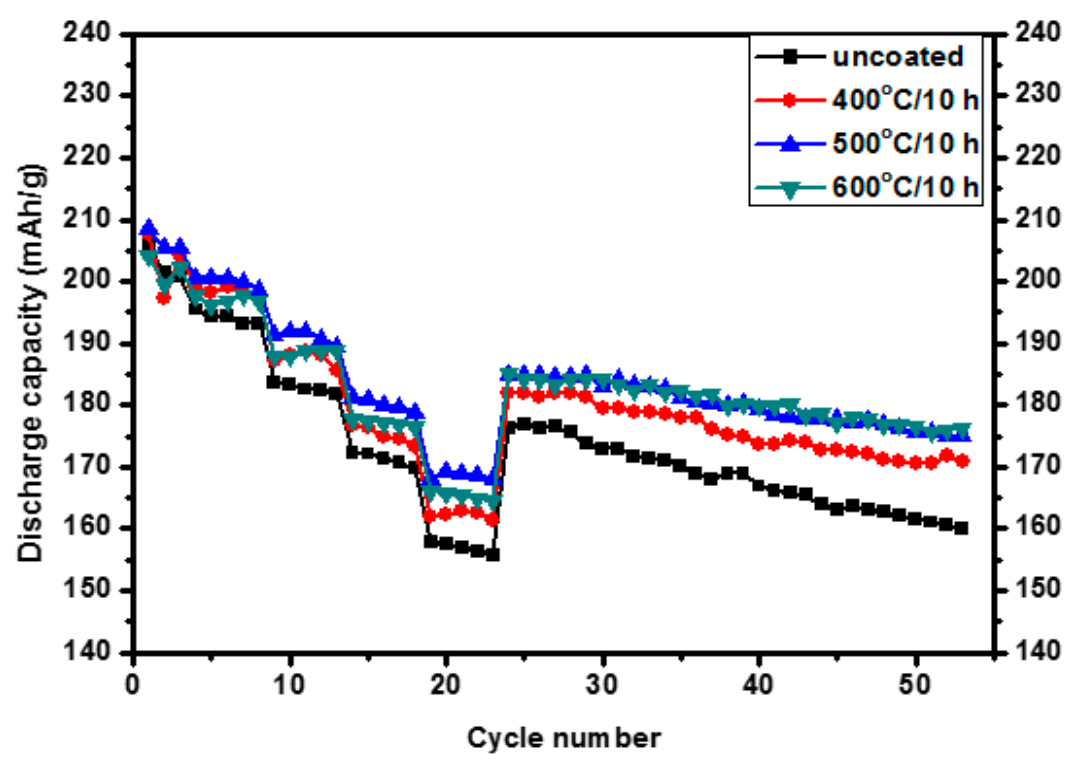

Figure 6. Electrochemical performance of the uncoated and 0.08 wt $\% \mathrm{Al}_{2} \mathrm{O}_{3}$-coated $\mathrm{Li}\left(\mathrm{Ni}_{0.6} \mathrm{Co}_{0.2} \mathrm{Mn}_{0.2}\right) \mathrm{O}_{2}$ samples annealed at different temperatures for $10 \mathrm{~h}$ and cycled between 3.0 and $4.5 \mathrm{~V}$ at various $\mathrm{C}$ rates. 


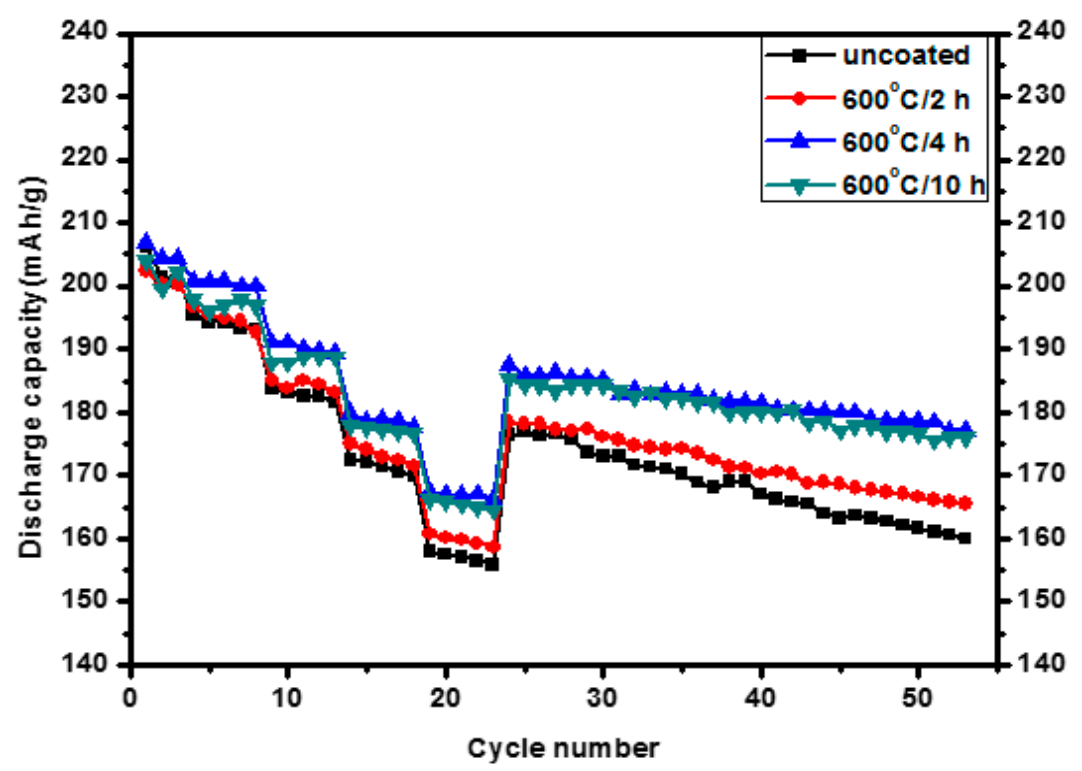

Figure 7. Electrochemical performance of the uncoated and 0.08 wt $\% \mathrm{Al}_{2} \mathrm{O}_{3}$-coated $\mathrm{Li}\left(\mathrm{Ni}_{0.6} \mathrm{Co}_{0.2} \mathrm{Mn}_{0.2}\right) \mathrm{O}_{2}$ samples annealed at $600{ }^{\circ} \mathrm{C}$ for different holding times and cycled between 3.0 and $4.5 \mathrm{~V}$ at various $\mathrm{C}$ rates.

\section{Conclusions}

In the present study, $\mathrm{Li}\left(\mathrm{Ni}_{0.6} \mathrm{Co}_{0.2} \mathrm{Mn}_{0.2}\right) \mathrm{O}_{2}$ cathode materials were coated with a relatively small amount of $\mathrm{Al}_{2} \mathrm{O}_{3}$ by simple surface modification in water media. The uncoated and coated $\mathrm{Li}\left(\mathrm{Ni}_{0.6} \mathrm{Co}_{0.2} \mathrm{Mn}_{0.2}\right) \mathrm{O}_{2}$ powders formed a polycrystalline hexagonal phase with a space group $\mathrm{R} \overline{3} \mathrm{~m}$. From SEM observation, it was confirmed that the particles of $\mathrm{Li}\left(\mathrm{Ni}_{0.6} \mathrm{Co}_{0.2} \mathrm{Mn}_{0.2}\right) \mathrm{O}_{2}$ cathode material were agglomerated and the discrete $\mathrm{Al}_{2} \mathrm{O}_{3}$ nano-particles of $10-15 \mathrm{~nm}$ were uniformly coated on the surface of the cathode material. The electrochemical properties of the samples were improved through $\mathrm{Al}_{2} \mathrm{O}_{3}$ coating of very low concentration; the optimum amount of $\mathrm{Al}_{2} \mathrm{O}_{3}$ additive was $0.08 \mathrm{wt} \%$ and the best heat treatment condition was $600{ }^{\circ} \mathrm{C}$ for $4 \mathrm{~h}$. In the case of the $0.08 \mathrm{wt} \% \mathrm{Al}_{2} \mathrm{O}_{3}$-coated $\mathrm{Li}\left(\mathrm{Ni}_{0.6} \mathrm{Co}_{0.2} \mathrm{Mn}_{0.2}\right) \mathrm{O}_{2}$ sample annealed at $600{ }^{\circ} \mathrm{C}$ for $4 \mathrm{~h}$, the initial discharge capacity at a rate of $0.05 \mathrm{C}$ over $3.0-4.5 \mathrm{~V}$ was $206.9 \mathrm{mAh} / \mathrm{g}$ and the capacity retention at $0.5 \mathrm{C}$ after 30 cycles was $94.5 \%$. It could be concluded that the $\mathrm{Li}\left(\mathrm{Ni}_{0.6} \mathrm{Co}_{0.2} \mathrm{Mn}_{0.2}\right) \mathrm{O}_{2}$ coated with nano- $\mathrm{Al}_{2} \mathrm{O}_{3}$ by simple surface modification and annealed at $600{ }^{\circ} \mathrm{C}$ for $4 \mathrm{~h}$ demonstrated improved electrochemical properties, including initial discharge capacity, rate capability, and cyclic performance. Finally, 0.08 wt \% $\mathrm{Al}_{2} \mathrm{O}_{3}$-coated $\mathrm{Li}\left(\mathrm{Ni}_{0.6} \mathrm{Co}_{0.2} \mathrm{Mn}_{0.2}\right) \mathrm{O}_{2}$ fabricated by the above method could be commercially used for the cathode material of lithium-ion secondary batteries.

Acknowledgments: This work was supported by the 2016 Research Fund of the University of Seoul. Also, this work was supported by the KIST institutional program (Project No. 2E27062).

Author Contributions: K.S.Y., C.-S.K., and K.R.I. conceived and designed the experiments; K.R.I. and Y.H.K. performed the experiments and analyzed the data; C.-S.K. contributed reagents/materials/analysis tools; K.S.Y. and K.R.I. wrote the paper.

Conflicts of Interest: The authors declare no conflict of interest.

\section{References}

1. Chen, J. Recent Progress in Advanced Materials for Lithium Ion Batteries. Materials 2013, 6, $156-183$. [CrossRef] [PubMed]

2. Zhou, A.; Lu, Y.; Wang, Q.; Xu, J.; Wang, W.; Dai, X.; Li, J. Sputtering $\mathrm{TiO}_{2}$ on $\mathrm{LiCoO}_{2} \mathrm{Composite}_{\text {Electrodes }}$ as a Simple and Effective Coating to Enhance High-voltage Cathode Performance. J. Power Sources 2017, 346, 24-30. [CrossRef] 
3. Yoo, K.S.; Cho, N.W.; Oh, Y.-J. Structural and Electrical Characterization of $\mathrm{Li}\left(\mathrm{Mn}_{1-\delta} \mathrm{Ti}_{\delta}\right)_{2} \mathrm{O}_{4}$ Electrode Materials. Solid State Ion. 1998, 113, 43-49. [CrossRef]

4. Bakierska, M.; Świętosławski, M.; Gajewaka, M.; Kowalczyk, A.; Piwowarska, Z.; Chmielarz, L.; Dziembaj, R.; Molenda, M. Enhancement of Electrochemical Performance of $\mathrm{LiMn}_{2} \mathrm{O}_{4}$ Spinel Cathode Material by Synergetic Substitution with Ni and S. Materials 2016, 9, 366. [CrossRef] [PubMed]

5. Rozier, P.; Tarascon, J.M. Review-Li-rich Layered Oxide Cathodes for Next-generation Li-ion Batteries: Chances and Challenges. J. Electrochem. Soc. 2015, 162, A2490-A2499. [CrossRef]

6. Yan, J.; Liu, H.; Wang, Y.; Zhao, X.; Mi, Y.; Xia, B. Enhanced High-temperature Cycling Stability of $\mathrm{Li}\left(\mathrm{Ni}_{1 / 3} \mathrm{Co}_{1 / 3} \mathrm{Mn}_{1 / 3}\right) \mathrm{O}_{2}$-coated $\mathrm{LiMn}_{2} \mathrm{O}_{4}$ as Cathode Material for Lithium Ion Batteries. Ionics 2015, 21, 1835-1842. [CrossRef]

7. Yue, P.; Wang, Z.; Li, X.; Xiong, X.; Wang, J.; Wu, X.; Guo, H. The Enhanced Electrochemical Performance of $\mathrm{Li}\left(\mathrm{Ni}_{0.6} \mathrm{Co}_{0.2} \mathrm{Mn}_{0.2}\right) \mathrm{O}_{2}$ Cathode Materials by Low Temperature Fluorine Substitution. Electrohcim. Acta 2013, 95, 112-118. [CrossRef]

8. Huang, H.; Yin, S.-C.; Nazar, L.F. Approaching Theoretical Capacity of $\mathrm{LiFePO}_{4}$ at Room Temperature at High Rates. Electrochem. Solid-State Lett. 2001, 4, A170-A172. [CrossRef]

9. Cao, H.; Zhang, Y.; Zhang, J.; Xia, B. Synthesis and Electrochemical Characteristics of Layered $\mathrm{Li}\left(\mathrm{Ni}_{0.6} \mathrm{Co}_{0.2} \mathrm{Mn}_{0.2}\right) \mathrm{O}_{2}$ Cathode Material for Lithium Ion Batteries. Solid State Ion. 2005, 176, 1207-1211. [CrossRef]

10. Liu, W.; Hua, W.; Zheng, Z.; Zhong, B.; Zhang, Z. Facile Synthesis of Hierarchical Porous Ni-rich Cathode Material with Superior High-rate Capability. Ionics 2016. [CrossRef]

11. Cheng, K.-L.; Mu, D.-B.; Wu, B.-R.; Wang, L.; Jiang, Y.; Wang, R. Electrochemical Performance of a Nickel-rich $\mathrm{Li}\left(\mathrm{Ni}_{0.6} \mathrm{Co}_{0.2} \mathrm{Mn}_{0.2}\right) \mathrm{O}_{2}$ Cathode Material for Lithium-ion Batteries under Different Cut-off Voltages. Int. J. Miner. Metall. Mater. 2017, 24, 342-351. [CrossRef]

12. Fu, C.; Zhou, Z.; Liu, Y.; Zhang, Q.; Zheng, Y.; Li, G. Synthesis and Electrochemical Properties of Mg-doped $\mathrm{Li}\left(\mathrm{Ni}_{0.6} \mathrm{Co}_{0.2} \mathrm{Mn}_{0.2}\right) \mathrm{O}_{2}$ Cathode Materials for Li-ion Battery. J. Wuhan Univ. Technol. Mater. Sci. Ed. 2011, 26, 211-215. [CrossRef]

13. Erickson, E.M.; Schipper, F.; Penki, T.R.; Shin, J.-Y.; Erk, C.; Chesneau, F.-F.; Markovsky, B.; Aurbach, D. Review-Recent Advances and Remaining Challenges for Lithium Ion Battery Cathodes II. Lithium-rich $\mathrm{xLi}_{2} \mathrm{MnO}_{3} \cdot(1-\mathrm{x}) \mathrm{Li}\left(\mathrm{Ni}_{\mathrm{a}} \mathrm{Co}_{\mathrm{b}} \mathrm{Mn}_{\mathrm{c}}\right) \mathrm{O}_{2}$. J. Electochem. Soc. 2017, 164, A6341-A6348. [CrossRef]

14. Wu, F.; Tian, J.; Su, Y.; Wang, J.; Zhang, C.; Bao, L.; He, T.; Li, J.; Chen, S. Effect of $\mathrm{Ni}^{2+}$ Content on Lithium/nickel disorder for Ni-rich Cathode Materials. ACS Appl. Mater. Interfaces 2015, 7, 7702-7708. [CrossRef] [PubMed]

15. Zhang, Z.; Zhu, S.; Huang, J.; Yan, C. Acacia Gum-assisted Co-precipitating Synthesis of $\mathrm{Li}\left(\mathrm{Ni}_{0.5} \mathrm{Co}_{0.2} \mathrm{Mn}_{0.3}\right) \mathrm{O}_{2}$ Cathode Material for Lithium Ion Batteries. Ionics 2015. [CrossRef]

16. Luo, W.B.; Li, X.H.; Dahn, J.R. Synthesis, Characterization and Thermal Stability of $\mathrm{Li}\left[\mathrm{Ni}_{1 / 3} \mathrm{Mn}_{1 / 3} \mathrm{Co}_{1 / 3}-\mathrm{Z}\right.$ $\left.(\mathrm{MnMg})_{\mathrm{z} / 2}\right] \mathrm{O}_{2}$. Chem. Mater. 2010, 22, 5065-5073. [CrossRef]

17. Santhanam, R.; Rambabu, B. High Rate Cycling Performance of $\mathrm{Li}_{1.05} \mathrm{Ni}_{1 / 3} \mathrm{Co}_{1 / 3} \mathrm{Mn}_{1 / 3} \mathrm{O}_{2}$ Materials Prepared by Sol-gel and Co-precipitation methods for Lithium-ion Batteries. J. Power Sources 2010, 195, 4313-4317. [CrossRef]

18. Yano, A.; Shikano, M.; Ueda, A.; Sakaebe, H.; Ogumi, Z. $\mathrm{LiCoO}_{2}$ Degradation Behavior in the High-voltage Phase Transition Region and Improved Reversibility with Surface Coating. J. Electrochem. Soc. 2017, 164, A6116-A6122. [CrossRef]

19. Shim, J.-H.; Cho, N.-H.; Lee, S. Synthesis and Characterization of $\mathrm{Mg}_{2} \mathrm{TiO}_{4}$-coated $\mathrm{LiCoO}_{2}$ as a Cathode Material for Lithium Ion Batteries. Electrochim. Acta 2017, 243, 162-169. [CrossRef]

20. Shen, B.; Zuo, P.; Fan, P.; Yang, J.; Yin, G.; Ma, Y.; Cheng, X.; Du, C.; Gao, Y. Improved Electrochemical Performance of $\mathrm{NaAlO}_{2}$-coated $\mathrm{LiCoO}_{2}$ for Lithium-ion Batteries. J. Solid State Electrochem. 2017, 21, 1195-1201. [CrossRef]

21. Wu, H.M.; Belharouak, I.; Abouimrane, A.; Sun, Y.-K.; Amine, K. Surface Modification of $\operatorname{LiNi}_{0.5} \mathrm{Mn}_{1.5} \mathrm{O}_{4}$ by $\mathrm{ZrP}_{2} \mathrm{O}_{7}$ and $\mathrm{ZrO}_{2}$ for Lithium-ion Batteries. J. Power Sources 2010, 195, 2909-2913. [CrossRef]

22. Shi, J.Y.; Yi, C.-W.; Kim, K. Improved electrochemical performance of $\mathrm{AlPO}_{4}$-coated $\mathrm{LiMn}_{1.5} \mathrm{Ni}_{0.5} \mathrm{O}_{4}$ electrode for lithium-ion batteries. J. Power Sources 2010, 195, 6860-6866. [CrossRef]

23. Chen, Y.; Zhang, Y.; Chen, B.; Wang, Z.; Lu, C. An Approach to Application for $\operatorname{Li}\left(\mathrm{Ni}_{0.6} \mathrm{Co}_{0.2} \mathrm{Mn}_{0.2}\right) \mathrm{O}_{2}$ Cathode Material as High Cutoff Voltage by $\mathrm{TiO}_{2}$ Coating. J. Power Sources 2014, 256, 20-27. [CrossRef] 
24. Chen, Y.; Zhang, Y.; Wang, F.; Wang, Z.; Zhang, Q. Improve the Structure and Electrochemical Performance of $\mathrm{Li}\left(\mathrm{Ni}_{0.6} \mathrm{Co}_{0.2} \mathrm{Mn}_{0.2}\right) \mathrm{O}_{2}$ Cathode Material by Nano- $\mathrm{Al}_{2} \mathrm{O}_{3}$ Ultrasonic Coating. J. Alloys Compd. 2014, 611, 135-141. [CrossRef]

25. Sun, S.; Du, C.; Qu, D.; Zhang, X.; Tang, Z. $\mathrm{Li}_{2} \mathrm{ZrO}_{3}$-coatedLi( $\left.\mathrm{Ni}_{0.6} \mathrm{Co}_{0.2} \mathrm{Mn}_{0.2}\right) \mathrm{O}_{2}$ for High-performance Cathode Material in Lithium-ion Battery. Ionics 2015, 21, 2091-2100. [CrossRef]

26. Xu, X.; Lee, S.; Jeong, S.; Kim, Y.; Cho, J. Recent Progress on Nanostructured 4 V Cathode Materials for Li-ion Batteries for Mobile Electronics. Mater. Today 2013, 16, 487-495. [CrossRef]

27. JCPDS-ICDD \#87-1564, version 2.1; The International Centre for Diffraction Data: Newtown Square, PA, USA, 2000.

28. Manikandan, P.; Periasamy, P.; Jagannathan, R. Microstructure-Twinning and Hexad Multiplet(s) in Lithium-rich Layered Cathode Materials for Lithium-ion Batteries. RSC Adv. 2014, 4, 40359-40367. [CrossRef]

29. Hua, W.; Zhang, J.; Zheng, Z.; Liu, W.; Peng, X.; Guo, X.-D.; Zhong, B.; Wang, Y.-J.; Wang, X. Na-doped Ni-rich $\mathrm{LiNi}_{0.5} \mathrm{Co}_{0.2} \mathrm{Mn}_{0.3} \mathrm{O}_{2}$ Cathode Material with Both High Rate Capability and High Tap Density for Lithium Ion Batteries. Dalton Trans. 2014, 43, 14824-14832. [CrossRef] [PubMed]

30. Song, H.G.; Park, Y.J. LiLaPO ${ }_{4}$-coated $\mathrm{Li}\left(\mathrm{Ni}_{0.5} \mathrm{Co}_{0.2} \mathrm{Mn}_{0.3}\right) \mathrm{O}_{2}$ and $\mathrm{AlF}_{3}$-coated $\mathrm{Li}\left(\mathrm{Ni}_{0.5} \mathrm{Co}_{0.2} \mathrm{Mn}_{0.3}\right) \mathrm{O}_{2}$ Blend Composites for Lithium Ion Batteries. Mater. Res. Bull. 2012, 47, 2843-2846. [CrossRef]

31. Shi, S.J.; Tu, J.P.; Mai, Y.J.; Zhang, Y.Q.; Tang, Y.Y.; Wang, X.L. Structure and Electrochemical Performance of $\mathrm{CaF}_{2}$ coated $\mathrm{Li} \mathrm{Mn} \mathrm{Mn}_{1 / 3} \mathrm{Ni}_{1 / 3} \mathrm{Co}_{1 / 3} \mathrm{O}_{2}$ Cathode Material for Li-ion Batteries. Electrochim. Acta 2012, 83, $105-112$. [CrossRef]

(C) 2017 by the authors. Licensee MDPI, Basel, Switzerland. This article is an open access article distributed under the terms and conditions of the Creative Commons Attribution (CC BY) license (http:/ / creativecommons.org/licenses/by/4.0/). 